Универзитет у Крагујевцу, Учитељски фракултет, Ужице

DOI 10.5937/kultura1756160P

УДК 371.3::811.163.41(497.11)"2014/2015"

811.163.41'271

оригиналан научни рад

\title{
УНАПРЕБИВАНЕ КУУТУРЕ
} ЈЕЗИНКОГ ИЗРАЖАВАНА УЧЕНИКАУ ШКОЛСКОМИ

\section{BAHШKOICKOM KOHTEKCTY}

Сажетак: Култура језичког изражавања као вештина комуникаиије, а самим тим и део опите културе подложна је утииају развојних и срединских фактора. Аутори у раду у ииљу утврђивања утииаја школе и ваншколских фактора на културу језичког изражавањ аученика млађег школског узраста испитују мишљења учитеља (N=273) о следећем: (а) који фактори у највећој мери доприносе унапређивању културе језичког изражавања ученика; (б) који фактори у највећој мери отежавају унапређивање културе језичког изражавања ученика. Према резултатима истраживања, школа највите доприноси унапређивағу културе језичког изражавања ученика, а средства масовне комуникаиије у највећој мери негативно утичу на развијағе језичких компетениија ученика млаЂег школског узраста. Овакви налази актуализују питање медијске писмености или медијског васпитања, у оквиру кога би родитељи и учитељи, односно школа били главни медијски соџијализатори у области културе језичког изражавања.

Кључне речи: култура језичког изражавања, породииа, икола, масмедији, вршњаци, ученик млађег школског узраста

\section{Увод}

Умешност правилног и лепог усменог и писаног изражавања тежња је савременог образованог појединца, која представља цивилизацијску тековину, део културе живљења и 
културе мишљења. Култура језичког изражавања одређује се као дисциплина која изучава правилну употребу језика у усменој и писаној комуникацији и културу слушања, односно „виши ниво владања говором (усменим и писаним) ${ }^{e е} .1$ Изграђена језичка култура омогућује појединцу да своје мисли изрази јасно, прецизно, сврсисходно, изражајно, придржавајући се принципа стандардне језичке норме, односно да при било ком облику формалне или неформалне комуникације постигне највиши ниво језичке компетенције. Широко научно-естетско подручје културе језичког изражавања, утемељено на основама лингвистике, естетике, поетике, теорије информације, логике и других сродних научних дисциплина, најбоље је сведочанство да је језик „нешто више од простог писања и говора преко којих се омогућује основно комуницирање и споразумевање". ${ }^{2}$ У том смислу, култивисање језика подразумева деловање различитих институција - васпитнообразовних, културних, јавних - у циљу унапређивања језичке културе.

\section{Теоријска полазишта}

Језичка писменост према Закону о основама система образоваға и васпитањ $a^{3}$ заузима прво место на листи циљева целокупног процеса васпитања и образовања. Циљ наставе српског језика јесте да ученици овладају основним законитостима српског књижевног језика на коме ће се усмено и писмено правилно изражавати. Један од задатака културе језичког изражавања јесте да усавршава језичко-изражајна средства, а њен крајњи циљ је успостављање квалитетне и сврсисходне комуникације. Квалитетно усмено и писано изражавање „омогућава ученику да се потврди као аутономно биће, способно да покаже своја знања и вредности, да искаже своје мишљење, ставове, одлуке". 4 Знање о језику које ученици стекну током школовања „има пресудну улогу у развијању и неговању језичких навика ученика, у популаризацији језичке теорије и њене примене у пракси и у унапређивању или снижавању нивоа језичке културе, а тиме

1 Цветановић, 3. Говорни узори ученицима даровитим за вештину говорења, у: Даровити и друштвена елита, уредила Гојков, Г. (2009), Вршац: Висока школа струковних студија за образовање васпитача, стр. 123.

2 Коковић, Д. (2007) Друштво и медијски изазови - увод у сочиологиjу масовних комуникаиија, Нови Сад: Филозофски факултет, Одсек за медијске студије, стр. 130.

3 Закон о основама система образовања и васпитања, „Службени гласник РСее, бр. 62/2016.

4 Петровачки, Љ. (2008) Методичка истраживања у настави српског језика и књижевности, Нови Сад: Филозофски факултет, Одсек за српски језик и лингвистику, стр. 9. 
и опште културе ученика". ${ }^{5}$ Иако се култивисањем језичког израза бави настава српског језика, а у извесној мери и настава других наставних предмета, сврха и задаци културе језичког изражавања требало би да буду усмерени ка спонтаној примени законитости језичке културе у свим аспектима свакодневног живота.

Култура језичког изражавања у најширем смислу данас преживљава својеврсну кризу, која је захватила све нивое школског система, али и медијску сферу и културне институције као значајне елементе ваншколског контекста. Непознавање језичке норме више се не сматра недостатком, релативизира се и карактерише као одређена врста немара. Медијско потенцирање рђавог говора и глорификовање непоштовања језичке норме представља „неку врсту друштвене забаве коja ce брзо преноси и на школску популацију". 6 Теоријска и емпиријска анализа показује да је настава говорне културе у основној школи „традиционална, што значи застарела, неорганизована и неефикасна и да говорна култура самих ученика није на одговарајућем нивоу". Р Резултати истраживања познавања и примене правописне норме у наставној пракси ученика основних и средњих школа и студената показују да се правописно, а самим тим и језичко знање ученика завршава са основном школом, као и да разлика у познавању ортографске норме није велика између средњошколаца и основаца. ${ }^{8}$ Истраживање особина језичке културе ученика у средњој школи показује да је говорна култура новијих генерација ученика све лошија, „да је писмено изражавање, уопште узевши, боље од њиховог усменог изражавања, а да је речник просечног ученика, посебно у говорном језику, врло оскудан, па се они без својих жаргонских поштапалица тешко изражавају".

Дакле, култура језичког изражавања у нашем друштву није у свом потпуном замаху, што је последица бројних социо-

5 Стевановић, J. (2013) Нормативно-стилистички аспекти културе изражавања средюошколаца, докторска дисертација, Филум, Крагујевац: Универзитет у Крагујевцу, стр. 29-30.

6 Златић, М. и Ђорђевић, J. (2014) Проблеми културе писменог изражавања у основној школи, Синтезе бр. 5, Крушевац: Висока школа струковних студија за васпитаче, стр. 87.

7 Јањић, М. (2008) Савремена настава говорне културе у основној школи, Нови Сад: Змај, стр. 215.

8 Брборић, В. (2004) Правопис српскога језика у наставној пракси, Београд: Чигоја штампа.

9 Петровачки, Љ. (1997) Нека запажања о култури изражавања ученика у средњој школи, Језик данас бр. 3, Нови Сад: Матица српска, стр. 8. 
лингвистичких чинилаца. ${ }^{10}$ Употреба савремених средстава електронске комуникације „под плаштом језичке економичности и информатичких слобода толерише, а заправо подстиче, разне неправилности у писаној комуникацији које се директно преливају и у свакодневни говор, а потом негативно утичу и на говорне ситуације које подразумевају употребу стандардног језика". ${ }^{11}$ Преовладава мишљење да се „последње генерације основаца не школују и васпитавају на језику књижевно-уметничких дела већ на језику медиja, језику ужих друштвених група где доминира арго, језику друштвених мрежа и СМС порука у којима има и елемената примитивних писама из прошлости и пиктографије". ${ }^{12}$ Поред неправилности, широко распрострањена примена електронских медија свесрдно потпомаже масовну и некритичку употребу страних речи и израза, посебно енглеских, која се негативно одражава на културу језичког изражавања. У ширем контексту, друштвене промене на нашим просторима од друге половине 20. века, као што су масовне миграције становништва из сеоских у градска подручја, које трају од завршетка Другог светског рата до данас, затим досељавање великог броја људи избеглих из ратом захваћених подручја бивше СФРЈ, на специфичан начин су се одразиле на језичку културу и на наш васпитнообразовни систем у целости.

Језичка култура ученика млађег школског узраста као вештина комуникације, а самим тим и део опште културе подложна је утицају развојних и срединских фактора. Важно место заузима породица као основно социјално окружење у коме се личност развија и формира. Образовни ниво и ниво развијености језичке културе родитеља, квалитет односа у породици, њихова друштвена вредност и васпитна оправданост у великој мери одређује квалитет језичке културе деце. Нарочито важне функције породице у том смислу су васпитна и у организацији слободног времена.

Школа има пресудну улогу у заснивању, изграђивању и унапређивању културе језичког изражавања ученика. У настави језика основним постигнућем сматра се развијање ученикове језичке компетенције која му осигурава укључивање у друштвену комуникацијску праксу у складу са стандардним

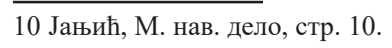

11 Ковачевић Микић, Д. Развијање језичких компетенција наставника и ученика и унапређивање наставе српског језика (област: усмено изражавање), у: Образовање и савремени универзитет, (2012), Ниш: Филозофски факултет, стр. 59-60.

12 Златић, М. и Ђорђевић, Ј. нав. дело, стр. 87. 
језиком. ${ }^{13}$ Језик се остварује, потврђује и проверава у језичко-васпитном подручју људског деловања, а оно се односи на учење језика у васпитно-образовним институцијама, јер је усвајање језика, као и учење својеврстан облик комуникације. ${ }^{14}$ Развој језичких компетенција ученика условљен је нивоом језичких - лингвистичких и комуникативних компетенција учитеља, који представљају говорне узоре најмлађима. Садржајима језичког изражавања у настави учитељи морају стваралачки приступати, уз стално занимање за проучавање и унапређивање језичког израза ученика и изналазити различите начине мотивисања ученика за увежбавање језичког израза.

Од најранијег периода живота дете је окружено светом који су за њега обликовали одрасли. У новије време масмедији, средства јавног информисања која имају бројну публику, ${ }^{15}$ а посебно електронски медији заузимају значајно место у том свету. Масмедијско окружење утиче на доживљај света, доживљај појединца самог, његов живот и здравље, као и систем вредности. „Уколико се текући тренд гледања телевизије настави, дете које је данас рођено, када напуни осамнаест година проводиће више времена пред телевизијским екраном него у било којој другој активности, изузев спавања". ${ }^{16}$ Сједињујући звук, слику, текст и покрет ови медији пресудно делују на свест и емоције деце, директно утичу на формирање њихових идентитета и склоности. На тај начин школа и породица престају бити почетно и најважније место васпитања у друштву, а њихову улогу преузимају електронски медији. ${ }^{17}$ Без обзира на бројне критике на рачун електронских медија, да негативно утичу на развој социјалних вештина, да отуђују децу од породице, вршњака, природе, игре, да узрокују лош успех у школи, да подстичу агресивно понашање и психичке промене везане за депресију и зависност, да негативно утичу на физички развој, електронски медији доминирају светом деце. Са друге стране, истраживања показују да добре телевизијске емисије, садржајно

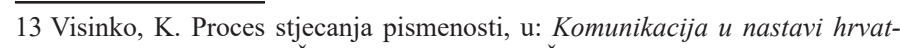
skoga jezika, uredili Šeši, M. i Barbaroša-Šikić, M. (2007), Jastrebarsko: Naklada Slap, str. 118.

14 Pavličević-Franić, D. (2005) Komunikacijom do gramatike, Razvoj komunikacijske kompetencije u ranom razdoblju usvajanja jezika, Zagreb: Alfa, str. 23.

15 Клајн, И. и Шипка, М. (2008) Речник страних речи и израза, Нови Сад: Прометеј, стр. 749.

16 Gidens, E. (2003) Sociologija, Beograd: Ekonomski fakultet, str. 469.

17 Vukić, T. i Youens, I. (2015) Televizijski program kao nastavno sredstvo u stjecanju osnovnoškolskih medijskih kompetencija, Medijska istraživanja god. 21, br. 1, Zagreb: Naklada Medijska istraživanja, str. 82. 
прихватљиве и примерене узрасту видео игре, као и сврсисходно служење Интернетом и мобилним телефоном имају позитиван утицај на доживљавање и понашање деце и одраслих у свакодневном животу и васпитно-образовном процеcy. ${ }^{18}$ Улога породице у усмеравању моћи тековина савремене цивилизације за добробит своје деце је пресудна. Уколико се развија култура гледања телевизије и коришћења Интернета и друштвених мрежа, може се избећи негативан утицај и ови медији се могу плански користити у сврху забаве, васпитања, образовања, па и у сврху унапређивања културе језичког изражавања.

Вршњаци као елеменат социјалног окружења у значајној мери могу утицати на изграђивање језичке компетенције ученика. Истраживања показују да деца усвајају бројне аспекте језика не од својих родитеља, нити од других припадника претходних генерација, већ управо једни од других, односно од оних који су им блиски по узрасту, интересовањима, нивоу језичког развоја, начину размишљања. ${ }^{19}$ Међутим, сагледавање улоге вршњака у унапређивању културе језичког изражавања ученика отвара питање квалитета тог утицаја на развијање језичке компетенције најмлађих.

Могућности комуницирања ученика млађег школског узраста условљене су њиховим развојним специфичностима. Хронолошки период од седме до једанаесте године у периодизацијама психичког развоја дели се на два узрасна периода: средње детињство - од седам до девет година и позно детињство или преадолесценција - од десет до дванаест година. Развој језичких компетенција нарочито је интензиван током млађег школског узраста и преплиће се са развојем мишљења, памћења и процеса учења. У школском периоду убрзано се проширују и дечија сазнања и дечији речник, усавршава усмено и писано изражавање. Током школовања деца треба да развију „металингвистичку свесност која осветљава развој двеју способности: анализе језичког знања у структуиране категорије и његове способности контроле мисаоних операција $а .{ }^{e 20}$ Контролом мисаоних процеса усмерава се пажња, која омогућава селекцију и процесирање, односно разумевање језичких информација. За трансфер на развојно виши ниво вербално-менталних структура пресудно је социјално искуство.

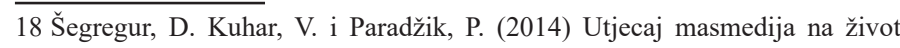
adolescenata, Media, culture and public relations br. 5/1, Zagreb: Hrvatsko komunikološko društvo, str. 81.

19 Pinker, S. (1995) The Language Instinct, New York: Harper Perennial.

20 Брковић, А. (2011) Развојна психологија, Чачак: Регионални центар за професионални развој запослених у образовању, стр. 262. 
Језичке компетенције као важно средство социјализације и подстицања психичког развоја у целини развијају се примањем постојећих језичких образаца којима се служе социјални узори. Интересовало нас је на који начин школа и развојни и средински елементи ваншколског контекста значајни за језичку комуникацију, утичу на културу изражавања ученика на почетку школовања.

\section{Методологија истраживања}

У цุиљу испитивања утицаја школе и ваншколских фактора на културу језичког изражавања ученика млађег школског узраста, истраживачки задаци односили су се на утврђивање: (а) који фактори у највећој мери доприносе унапређивању културе језичког изражавања ученика; (б) који фактори у највећој мери отежавају унапређивање културе језичког изражавања ученика.

Истраживање је засновано на примени дескриптивне мето$\partial e$, а обављено је анкетирањем. Анкетним упитником затвореног типа испитиван је утицај: породице, школе, средстава масовне комуникачије, вршњака, особености ученика, као фактора који доприносе или отежавају унапређивање културе језичког изражавања. Истраживање је било анонимно, како би се избегло давање пожељних одговора.

Узорак учитеља одабран је из популације запослених школске 2014/2015. године у основним школама у Републици Србији и чинило га је 273 учитеља из 25 основних школа из 7 управних округа.

Добијени подаци обрађени су у статистичком пакету IBM SPSS Statistics 20, а исказани су статистичким мерама пребројавања и релативног односа, а од статистичких тестова примењен је Ні квадрат као непараметријски поступак.

\section{Резултати истраживања и дискусија}

\section{1. Фактори који доприносе унапређивању културе језичког изражавања}

Резултати испитивања доприноса појединих фактора унапређивању културе језичког изражавања показују да скоро половина анкетираних учитеља (132 или 48,3\%) на прво место према доприносу култури језичког изражавања ученика ставља школу (Графикон 1, Табела 1). Од ваншколских фактора, учитељи највећи значај за унапређивање језичке културе ученика придају породиии (98 или 35,9\%), затим средствима масовне комуникачије (20 или 7,3\%), особеностима ученика (10 или $3,7 \%)$ и вршњащима (6 или $2,2 \%)$. Најмањи 
проценат учитеља (7 или 2,6\%) допунили су понуђену листу следећим факторима: читалачке навике, читалачка интересовања, социјална средина или комбинацијом појединих односно свих понуђених фактора унапређивања културе језичког изражавања.

Добијени резултати не изненађују ако се има у виду да је развијање квалитетне и сврсисходне комуникације основни циљ наставе језичког изражавања, а унапређивање језичких компетенција један од важнијих задатака васпитнообразовног система.

Графикон 1: Фактори који доприносе унапређивању културе језичког изражавања ученика

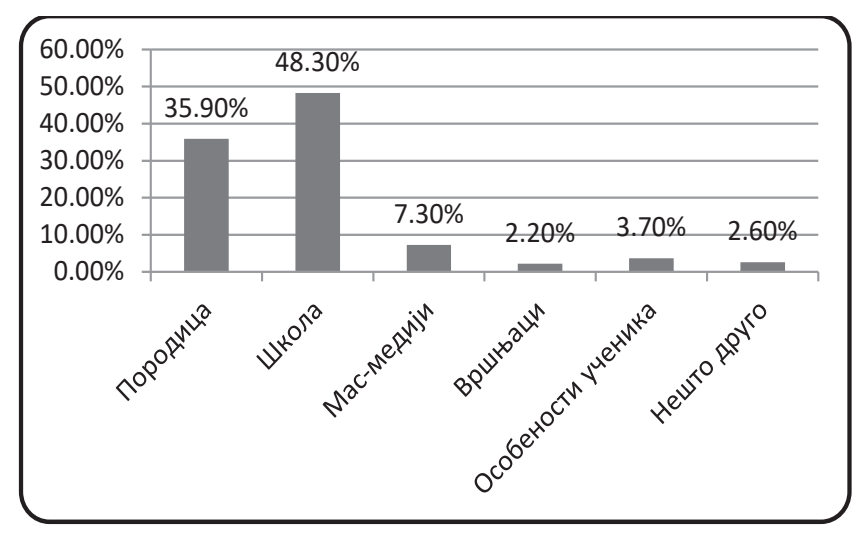

Анализирајући ставове учитеља различитог радног искуства, уочавају се извесне разлике у проценту учитеља који се опредељују за поједине факторе који у најврећој мери доприносе унапређивању културе језичког изражавања ученика (Табела 1). Приближно исти проценат анкетираних који имају до 30 година радног искуства сматра да су школа и породица фактори који у највећој мери утичу на развијање културе изражавања најмлађих ученика. Нешто већи проценат учитеља који имају више од 30 година радног стажа (14 или 60,9\%) сматра да школа у највећој мери утиче на унапређивање језичке културе ученика. Са друге стране, учитељи који имају мање искуства у настави сматрају да средства масовних комуникаиија у највећој мери утичу на унапређивање ученичког језичког израза. 
ДАЛИБОРКА ПУРИЋ И ЖАНА БОЈОВИЋ

Табела 1: Фактори који доприносе унапређивағу културе језичког изражавања ученика у зависности од радног искуства учитеља

\begin{tabular}{|c|c|c|c|c|c|c|c|}
\hline $\begin{array}{c}\text { Радно } \\
\text { искуство }\end{array}$ & Породица & Школа & $\begin{array}{l}\text { Мас- } \\
\text { медији }\end{array}$ & Вршњаци & $\begin{array}{c}\text { Особености } \\
\text { ученика }\end{array}$ & $\begin{array}{l}\text { Нешто } \\
\text { друго }\end{array}$ & Укупно \\
\hline $0-10$ & $\begin{array}{l}21 \\
\quad 36,8 \% \\
\end{array}$ & $\begin{array}{l}28 \\
49,1 \%\end{array}$ & $\begin{array}{ll}5 & \\
& 8,8 \% \\
\end{array}$ & $0 \%$ & $3,5 \%$ & $\begin{array}{|ll|}1 & \\
& 1,8 \% \\
\end{array}$ & $\begin{array}{l}57 \\
100 \% \\
\end{array}$ \\
\hline $11-20$ & $\begin{array}{l}35 \\
\quad 35,4 \% \\
\end{array}$ & $\begin{array}{l}47 \\
47,5 \% \\
\end{array}$ & $\begin{aligned} 12 \\
12,1 \% \\
\end{aligned}$ & $0 \%$ & $2,0 \%$ & $\begin{array}{|lr|}3 & \\
& 3,0 \% \\
\end{array}$ & $\begin{array}{l}99 \\
100 \% \\
\end{array}$ \\
\hline $21-30$ & $\begin{array}{l}35 \\
\quad 37,2 \% \\
\end{array}$ & $\begin{array}{l}43 \\
45,8 \% \\
\end{array}$ & $\begin{array}{ll}3,2 \% \\
\end{array}$ & $5,3 \%$ & $5,3 \%$ & 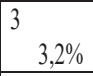 & $\begin{array}{l}94 \\
100 \% \\
\end{array}$ \\
\hline $\begin{array}{l}\text { Више од } \\
30\end{array}$ & $30,5 \%$ & $\begin{array}{l}14 \\
\quad 60,9 \% \\
\end{array}$ & $0 \%$ & $4,3 \%$ & $4,3 \%$ & $\begin{array}{ll}0 & \\
& 0 \% \\
\end{array}$ & $\begin{array}{l}23 \\
100 \% \\
\end{array}$ \\
\hline Укупно & $\begin{array}{l}98 \\
\quad 35,9 \%\end{array}$ & $\begin{array}{l}132 \\
48,3 \%\end{array}$ & $\begin{array}{l}20 \\
\quad 7,3 \% \\
\end{array}$ & $2,2 \%$ & $3,7 \%$ & $\begin{array}{ll}7 & \\
& 2,6 \%\end{array}$ & $\begin{array}{l}273 \\
100 \%\end{array}$ \\
\hline
\end{tabular}

$$
\chi^{2}=18,818, \quad \mathrm{df}=15, \quad \mathrm{p}=0,222
$$

Тестирањем статистичке значајности уочених разлика добија се да $\chi^{2}=18,818$ уз $\mathrm{df}=15$ није статистички значајан, што указује да не постоје разлике у процени доприноса појединих фактора унапређивању културе језичког изражавања ученика млађег школског узраста у зависности од година радног искуства учитеља.

Упоређујући ставове учитеља различитог степена образовања о утицају појединих чинилаца на унапређивање културе језичког изражавања уочава се да знатно већи проценат учитеља који имају више образовање (26 или 59,1\%) у односу на високообразоване (106 или 46,3\%) издвајају шко$л у$ као фактор који у највећој мери утиче на унапређивање културе језичког изражавања ученика (Табела 2). Са друге стране, нешто већи проценат учитеља који су стекли академско образовање као најзначајнији фактор који доприноси унапређивању језичке културе ученика наводи породииу (84 или $36,7 \%$ ) и средства масовних комуникащија (19 или 8,3\%).

Табела 2: Фактори који доприносе унапређивању културе језичког изражавањ аученика у зависности од стручне спреме учитељь

\begin{tabular}{|c|c|c|c|c|c|c|c|}
\hline $\begin{array}{l}\text { Стручна } \\
\text { спрема }\end{array}$ & Породица & Школа & $\begin{array}{l}\text { Мас- } \\
\text { медији }\end{array}$ & Вршњаци & $\begin{array}{c}\text { Особености } \\
\text { ученика }\end{array}$ & $\begin{array}{l}\text { Нешто } \\
\text { друго }\end{array}$ & Укупно \\
\hline Виша & $\begin{array}{l}14 \\
\quad 31,8 \%\end{array}$ & $\begin{array}{l}26 \\
59,1 \%\end{array}$ & $\begin{array}{ll}1 & \\
& 2,3 \% \\
\end{array}$ & $0 \%$ & $2,3 \%$ & $\begin{array}{ll}2 & \\
4,5 \%\end{array}$ & $\begin{array}{l}44 \\
100 \%\end{array}$ \\
\hline Висока & $\begin{array}{l}84 \\
\quad 36,7 \%\end{array}$ & $\begin{array}{l}106 \\
46,3 \%\end{array}$ & $\begin{array}{r}19 \\
8,3 \%\end{array}$ & $2,6 \%$ & $3,9 \%$ & $\begin{array}{ll}5 & \\
& 2,2 \%\end{array}$ & $\begin{array}{l}229 \\
100 \%\end{array}$ \\
\hline Укупно & $\begin{array}{l}98 \\
\quad 35,9 \%\end{array}$ & $\begin{array}{l}132 \\
48,3 \%\end{array}$ & $\begin{array}{l}20 \\
7,3 \%\end{array}$ & $2,2 \%$ & $3,7 \%$ & $\begin{array}{l}7,6 \% \\
\end{array}$ & $\begin{array}{l}273 \\
100 \%\end{array}$ \\
\hline
\end{tabular}

$$
\chi^{2}=5,555, \quad \mathrm{df}=5, \quad \mathrm{p}=0,352
$$


Уочене разлике нису статистички значајне $\left(\chi^{2}=5,555, \mathrm{df}=5\right.$, $\mathrm{p}=0,352)$, што указује да на процену доприноса појединих фактора унапређивању културе језичког изражавања ученика млађег школског узраста не утиче образовни ниво учитеља.

\section{Фактори који отежавају унапређивање културе језичког изражавана}

Један од задатака истраживања односио се на испитивање мишљења учитеља о факторима који у највећој мери отежавају унапређивање културе језичког изражавања ученика млађег школског узраста. Највећи проценат анкетираних учитеља (129 или 47,2\%) сматра да средства масовне комуникащије у највећој мери негативно утичу на културу језичког изражавања ученика. Учитељи затим наводе породииу (51 или 18,7\%), вршњаке (48 или 17,6\%) и особености ученика (28 или 10,2\%), као ваншколске факторе који у највећој мери отежавају унапређивање културе језичког изражавања ученика. Мање од 5\% анкетираних учитеља (13 или 4,8\%) мишљења је да школа негативно утиче на језичко изражавање ученика млађег школског узраста. Допуњујући листу фактора који отежавају развијање културе изражавања најмлађих основаца испитивани учитељи (4 или 1,5\%) као основни узрок навели су: социјалну средину, стихијски начин васпитања и све наведене факторе заједно.

На нужност озбиљнијег уважавања медија као социјализацијског фактора указују и друга истраживања. ${ }^{21}$ Када су у питању најмлађи ученици основне школе и унапређивање културе језичког изражавања, при коришћењу медијских садржаја неопходно је посредовање родитеља, других чланова породице и учитеља, односно школе у њиховом коришћењу. У том смислу, потребно је посебну пажњу посветити медијском васпитању, како би се спречио негативан утицај на развијање језичке компетенције ученика млађег школског узраста.

21 Lipovčak, S. Mediji - druga zbilja?, u: Rasprave, ogledi i interpretacije, uredio Šikić, A. (2006), Zagreb: Hrvatska sveučilišna naklada; Roberts, D. F. and Foehr, U. G. (2004) Kids \& media in America, Cambridge University Press; Šegregur, D. Kuhar, V. i Paradžik, P. (2014) Utjecaj masmedija na život adolescenata, Media, culture and public relations br. 5/1, Zagreb: Hrvatsko komunikološko društvo. 
ДАЛИБОРКА ПУРИЋ И ЖАНА БОЈОВИЋ

Графикон 2: Фактори који отежавају унапређивање културе језичког изражавања ученика

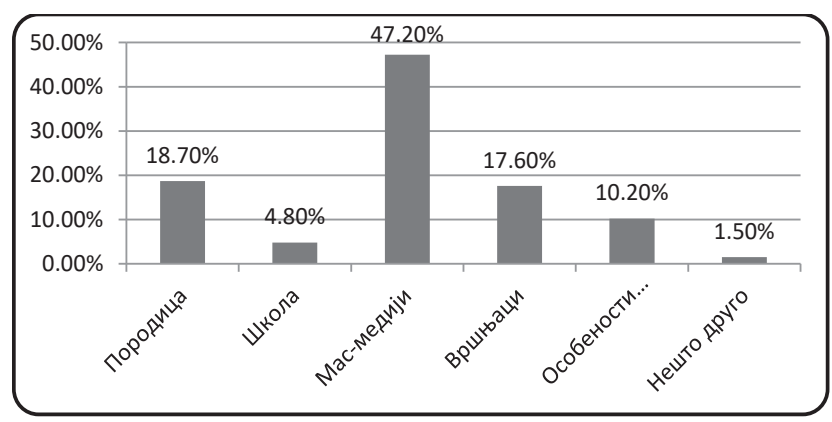

Испитиване су разлике у ставовима учитеља о негативном утицају појединих фактора на унапређивање културе језичког изражавања ученика под утицајем радног искуства као независне варијабле (Табела 3). Резултати показују да са бројем година радног стажа расте и проценат учитеља који одређују средства масовне комуникације као фактор који у највећој мери отежава унапређивање језичке културе ученика. Приближно исти проценат анкетираних учитеља који имају од 10 до 30 година радног искуства породииу издваја као фактор који у највећој мери отежава унапређивање културе језичког изражавања ученика, док њихове ставове дели нешто мање учитеља на почетку каријере (8 или 14,0\%) и знатно мањи проценат најискуснијих (2 или 8,7\%). Такође, приближно исти проценат учитеља који у настави раде између 10 и 30 година вршњаке одређује као фактор који у највећој мери негативно утиче на језичку културу најмлађих ученика, док скоро дупло већи проценат најнеискуснијих (16 или $28,1 \%$ ) и скоро дупло мањи проценат најискуснијих (2 или 8,7\%) сматра да вршњаци у највећој мери отежавају унапређивање језичке културе ученика млађег школског узраста.

Табела 3: Фактори који отежавају унапређивање културе језичког изражавања ученика у зависности од радног искуства учитеља

\begin{tabular}{|c|c|c|c|c|c|c|c|}
\hline $\begin{array}{c}\text { Стручна } \\
\text { спрема }\end{array}$ & Породица & Школа & $\begin{array}{l}\text { Мас- } \\
\text { медији }\end{array}$ & Вршњаци & \begin{tabular}{|c} 
Особености \\
ученика
\end{tabular} & $\begin{array}{l}\text { Нешто } \\
\text { друго }\end{array}$ & Укупно \\
\hline Више & 6 & 0 & 20 & 13 & 3 & 2 & 44 \\
\hline Виша & $13,6 \%$ & $0 \%$ & $45,5 \%$ & $29,5 \%$ & $6,8 \%$ & $4,6 \%$ & $100 \%$ \\
\hline Висока & $\begin{array}{l}45 \\
\quad 19,6 \%\end{array}$ & $\begin{array}{l}13 \\
5.7 \%\end{array}$ & $\begin{array}{l}109 \\
47,6 \%\end{array}$ & $\begin{array}{ll}35 & \\
& 15,3 \%\end{array}$ & $10,9 \%$ & $\begin{array}{ll}2 & \\
0.9 \%\end{array}$ & $\begin{array}{l}229 \\
100 \%\end{array}$ \\
\hline Укупно & $\begin{array}{l}51 \\
\quad 18,7 \%\end{array}$ & $\begin{array}{l}13 \\
4,8 \%\end{array}$ & $\begin{array}{l}129 \\
47,2 \%\end{array}$ & $\begin{array}{ll}48 & \\
17,6 \%\end{array}$ & $10,2 \%$ & $\begin{array}{ll}4 & \\
& 1,5 \%\end{array}$ & $\begin{array}{l}273 \\
\quad 100 \%\end{array}$ \\
\hline
\end{tabular}

$$
\chi^{2}=20,927, \quad \mathrm{df}=15, \quad \mathrm{p}=0,139
$$


Резултати Ні квадрат теста показују да уочене разлике нису статистички значајне $\left(\chi^{2}=20,927, \mathrm{df}=15, \mathrm{p}=0,139\right)$, што указује да на процену негативног утицаја појединих фактора на унапређивање културе језичког изражавања ученика млађег школског узраста не утиче радно искуство учитеља.

Анализа ставова учитеља различитог образовног нивоа показује извесне разлике у издвајању фактора који отежавају унапређивање културе језичког изражавања ученика (Табела 4). Нешто већи проценат учитеља који имају високо образовање (109 или 47,6\%) у односу на анкетиране учитеље са вишим образовањем (20 или 45,5\%) мишљења је да средства масовне комуникаиије у највећој мери негативно утичу на језичку културу ученика млађег школског узраста. Такође нешто већи проценат високообразованих (45 или $19,6 \%)$ у односу на учитеље са вишом стручном спремом (6 или 13,6\%) издвајају породицу као фактор који отежава унапређивање културе језичког изражавања. Са друге стране, скоро дупло већи проценат учитеља који имају више образовање (13 или 29,5\%) у односу на оне са академским образовањем (35 или 15,3\%) сматрају да су вршьаии фактор који има највећи негативан утицај на унапређивање културе језичког изражавања ученика. Интересантно је указати на податак да само високообразовани, и то у мањем проценту (13 или 5,7\%) издвајају школу као основни елеменат негативног утицаја на језичку културу ученика.

Табела 4: Фактори који отежавају унапређивање културе језичког изражавањ а ученика у зависности од стручне

спреме учитеља

\begin{tabular}{|c|c|c|c|c|c|c|c|}
\hline $\begin{array}{l}\text { Стручна } \\
\text { спрема }\end{array}$ & Породица & Школа & $\begin{array}{l}\text { Мас- } \\
\text { медији }\end{array}$ & Вршњаци & \begin{tabular}{|c|} 
Особености \\
ученика
\end{tabular} & $\begin{array}{l}\text { Нешто } \\
\text { друго }\end{array}$ & Укупно \\
\hline & 6 & 0 & 20 & \begin{tabular}{|l|}
13 \\
\end{tabular} & 3 & 2 & \\
\hline Виша & $13,6 \%$ & $0 \%$ & $45,5 \%$ & $29,5 \%$ & $6,8 \%$ & $4,6 \%$ & $100 \%$ \\
\hline Висока & $\begin{array}{l}45 \\
19,6 \%\end{array}$ & 13 5 & $\begin{array}{l}109 \\
47,6 \%\end{array}$ & $\begin{array}{|ll|}35 & \\
& 15,3 \% \\
\end{array}$ & $10,9 \%$ & 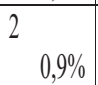 & $\begin{array}{r}229 \\
100 \%\end{array}$ \\
\hline Укупно & \begin{tabular}{|lr}
51 & \\
& $18,7 \%$ \\
\end{tabular} & $\begin{array}{ll}13 & \\
4,8 \% \\
\end{array}$ & $\begin{array}{r}129 \\
47,2 \% \\
\end{array}$ & \begin{tabular}{|r|}
48 \\
\\
$17,6 \%$ \\
\end{tabular} & $10,2 \%$ & 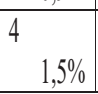 & $\begin{array}{l}273 \\
100 \% \\
\end{array}$ \\
\hline
\end{tabular}

Тестирајући статистичку значајност уочених разлика добија се да је $\chi^{2}=11,519$ уз $\mathrm{df}=5$ степени слободе статистички значајан на нивоу 0,05 , што значи да постоје значајне разлике у ставовима учитеља различитог образовног нивоа о негативном утицају појединих фактора на културу језичког изражавања ученика млађег школског узраста. Учитељи вишег образовног нивоа свеснији су негативног утицаја појединих фактора на унапређивање културе језичког изражавања 
ученика, што може бити резултат посвећивања пажње овом проблему у оквиру изучавања појединих студијских предмета на учитељским факултетима.

\section{Закључак}

С обзиром на то да потребу за успешном комуникацијом са другим члановима говорне заједнице имају сви људи, припремање за такву комуникацију мора бити широко постављено, мора бити опште, друштвено организовано и усмерено, са јасно одређеним циљем и задацима. ${ }^{22}$ Такав циљ и задатке требало би да оствари пре свега школа, односно настава српског језика, али и осталих наставних предмета. Скоро половина учитеља анкетираних у овом истраживању (132 или 48,3\%) мишљења је да управо школа у највећој мери доприноси унапређивању културе језичког изражавања ученика млађег школског узраста. Добијени резултат имплицира следеће: ако учитељи имају у виду значај наставе чији су непосредни организатори и реализатори на развијање језичких компетенција ученика, онда би и квалитет њихових активности на плану унапређивања културе језичког изражавања ученика требало да буде примерен том значају. Главни исход образовања треба да буде стицање функционалних, применљивих знања, па у складу са тим, Стандарди компетенција за професију наставника одређују да је основна улога наставника да развија кључне компетенције код ученика које их оспособљавају за живот и рад, и на тај начин им пружа основу за даље учење. Посебно данас, када култура језичког изражавања у најширем смислу преживљава својеврсну кризу, један од важнијих задатака наставе српског језика је „непрекидно повезивање прописаних наставних садржаја са социјалним и језичким окружењем ученика, како би се код ученика развијала свест о потреби неговања и заштите стандардног српског језика, уз повезивање градива са стварним животом и развијање функционалног (применљивог) знања". ${ }^{23}$

Радно искуство и стручна спрема учитеља као независне варијабле не утичу на процену доприноса појединих фактора унапређивању културе језичког изражавања ученика.

Развијање језичких компетенција ученика млађег школског узраста поред школе у значајној мери обликује и ваншколско

22 Јањић, М. (2008) Савремена настава говорне културе у основној иколи, Нови Сад: Змај, стр. 219.

23 Ковачевић Микић, Д. Развијање језичких компетенција наставника и ученика и унапређивање наставе српског језика (област: усмено изражавање), у: Образовање и савремени универзитет, (2012), Ниш: Филозофски факултет, стр. 64. 
окружење. Резултати нашег истраживања показују да највећи број анкетираних учитеља (129 или 47,2\%) издвајају средства масовне комуникачије као фактор који у највећој мери отежава развијање културе језичког изражавања ученика млађег школског узраста. Радно искуство учитеља не утиче на процену негативног утицаја појединих фактора на унапређивање културе језичког изражавања ученика, док постоје статистички значајне разлике у ставовима учитеља различитог образовног нивоа о томе који фактори отежавају развијање језичких компетенција ученика млађег школског узраста.

Свака нова генерација деце одраста у окружењу које је богатије медијима и припадајућим садржајима, због чега се мења и перцепција и потенцијал медијског утицаја на децу. Што су деца млађа, потенцијални утицај медија знатно је већи него утицај родитеља, школе или вршњака, и то зато што се чини да га је индивидуалним напорима знатно теже дозирати и контролисати. ${ }^{24}$ Овакви налази актуализују питање медијске писмености или медијског васпитања, који би оспособљавали најмлађе ученике да разликују стварност и фикцију, да селективно бирају садржаје, спознају значења приказаног, препознају позитивне и негативне карактеристике медија. ${ }^{25} \mathrm{C}$ обзиром на чињеницу да су масовни медији неизбежан елеменат свакодневице и да се њихов број прогресивно повећава, неопходно је за њихово коришћење оспособити нарочито ученике млађег школског узраста, на које имају највише потенцијалног негативног утицаја. Иако се школе и учитељи, односно наставници све чешће помињу као могући модератори дечије медијске оспособљености, родитељи се сматрају главним медијским социјализаторима. ${ }^{26}$ Најбољи резултати у области културе језичког изражавања могли би се остварити удруживањем и континуираном сарадњом породице и школе, као примарних социјализацијских агенаса.

24 Ilišin, V. (2003) Mediji u slobodnom vremenu djece i komunikacija o medijskim sadržajima, Medijska istraživanja god. 9, br. 2, Zagreb: Naklada Medijska istraživanja.

25 Gunter, B. and McAleer, J. (1997) Children and Television, London and New York: Routledge, p. 2; Košir, M. Zgrabljić, N. i Ranfil, R. (1999) Život s medijima, Zagreb: Doron, str. 29.

26 Ilišin, V. nav. delo. 


\section{ЛИТЕРАТУРА:}

Брборић, В. (2004) Правопис српскога језика у наставној пракси, Београд: Чигоја штампа.

Брковић, А. (2011) Развојна психологија, Чачак: Регионални центар за професионални развој запослених у образовању.

Цветановић, 3. Говорни узори ученицима даровитим за вештину говорења, у: Даровити и друштвена елита, уредила Гојков, Г. (2009), Вршац: Висока школа струковних студија за образовање васпитача, стр. 122-135.

Gidens, E. (2003) Sociologija, Beograd: Ekonomski fakultet.

Gunter, B. and McAleer, J. (1997) Children and Television, London and New York: Routledge.

Ilišin, V. (2003) Mediji u slobodnom vremenu djece i komunikacija o medijskim sadržajima, Medijska istraživanja god. 9, br. 2, Zagreb: Naklada Medijska istraživanja, str. 9-34.

Јањић, М. (2008) Савремена настава говорне културе у основној школи, Нови Сад: Змај.

Клајн, И. и Шипка, М. (2008) Речник страних речи и израза, Нови Сад: Прометеј.

Коковић, Д. (2007) Друштво и медијски изазови - увод у сочииологију масовних комуникација, Нови Сад: Филозофски факултет, Одсек за медијске студије.

Košir, M., Zgrabljić, N. i Ranfil, R. (1999) Život s medijima, Zagreb: Doron.

Ковачевић Микић, Д. Развијање језичких компетенција наставника и ученика и унапређивање наставе српског језика (област: усмено изражавање), у: Образовање и савремени универзитет, (2012), Ниш: Филозофски факултет, стр. 58-72.

Lipovčak, S. Mediji - druga zbilja?, u: Rasprave, ogledi i interpretacije, uredio Šikić, A. (2006), Zagreb: Hrvatska sveučilišna naklada.

Pavličević-Franić, D. (2005) Komunikacijom do gramatike, Razvoj komunikacijske kompetencije u ranom razdoblju usvajanja jezika, Zagreb: Alfa.

Петровачки, Љ. (1997) Нека запажања о култури изражавања ученика у средњој школи, Језик данас бр. 3, Нови Сад: Матица српска, стр. 7-10.

Петровачки, Љ. (2008) Методичка истраживања у настави српског језика и књижевности, Нови Сад: Филозофски факултет, Одсек за српски језик и лингвистику.

Pinker, S. (1995) The Language Instinct, New York: Harper Perennial.

Roberts, D.F. and Foehr, U. G. (2004) Kids \& media in America, Cambridge University Press. 
Стевановић, J. (2013) Нормативно-стилистички аспекти културе изражавања средњошколаиа, докторска дисертација, Филум, Универзитет у Крагујевцу, Крагујевац.

Šegregur, D., Kuhar, V. i Paradžik, P. (2014) Utjecaj masmedija na život adolescenata, Media, culture and public relations br. 5/1, Zagreb: Hrvatsko komunikološko društvo, str. 81-86.

Visinko, K. Proces stjecanja pismenosti, u: Komunikacija u nastavi hrvatskoga jezika, uredili Šeši, M. i Barbaroša-Šikić, M. (2007), Jastrebarsko: Naklada Slap, str. 110-121.

Vukić, T. i Youens, I. (2015) Televizijski program kao nastavno sredstvo u stjecanju osnovnoškolskih medijskih kompetencija, Medijska istraživanja god. 21, br. 1, Zagreb: Naklada Medijska istraživanja, str. 79-100.

Закон о основама система образовања и васпитања, „Службени гласник РС", бр. 62/2016.

Златић, М. и Ђорђевић, J. (2014) Проблеми културе писменог изражавања у основној школи, Синтезе бр. 5, Крушевац: Висока школа струковних студија за васпитаче, стр. 85-94.

\author{
Daliborka Purić and Žana Bojović \\ University in Kragujevac, Teachers Training Faculty, Užice
DEVELOPING THE CULTURE OF LINGUISTIC EXPRESSION OF PUPILS INSIDE AND OUTSIDE THE SCHOOL ENVIRONMENT

\begin{abstract}
The culture of linguistic expression as a communication skill, and therefore part of general culture, is subject to a number of developmental and environmental influences. In this paper, the authors, wanting to determine the impact of school and non-school factors on the culture of the linguistic expression of pupils at a younger school age, examine the opinions of teachers $(\mathrm{N}=273)$ on the following: (a) Which factors largely contribute to the development of the culture of linguistic expression of pupils? (b) Which factors largely hinder the development of the culture of linguistic expression of pupils? According to the survey, school contributes most to the development of the culture of linguistic expression in pupils, while means of mass communication have the greatest negative impact on the development of language competences in pupils at a younger school age. These findings emphasize the issue of media literacy or media education, in which parents, teachers and schools, respectively, would be the main media socializators in the field of the culture of linguistic expression.
\end{abstract}

Key words: culture of linguistic expression, family, school, mass media, peers, a pupil at younger school age 